\title{
Effect of Fertilizer Levels and Foilar Application on Morphological Characters, Nutrient Content and Yield of Cotton
}

\author{
A. N. Deshpande ${ }^{1}$, R. S. Masram ${ }^{1}$ and B. M. Kamble ${ }^{2^{*}}$ \\ ${ }^{1}$ Dept. of Soil Science and Agricultural Chemistry, Mahatma Phule Agricultural University, Rahuri, Ahemadnagar District \\ Maharashtra (413 722), India \\ ${ }^{2}$ Dept. of Soil Science and Agricultural Chemistry, Agricultural Research Station, K.Digraj, Sangli District, \\ Maharashtra (416 305) India
}

\section{Article History}

Manuscript No. AR968

Received in $15^{\text {th }}$ October, 2014

Received in revised form $25^{\text {th }}$ March, 2015

Accepted in final form $5^{\text {th }}$ April, 2015

\section{Correspondence to}

*E-mail: bmkamble2007@rediffmail.com

\section{Keywords}

Cotton, fertilizer, morphology, nutrient content, reddening, yield

\begin{abstract}
A field experiment on effect of fertilizer levels and foliar application on morphophysiological, nutrient content, reddening and yield of cotton on Vertisol" was conducted at Cotton Improvement Project, Mahatma Phule Krishi Vidyapeeth, Rahuri, Maharashtra, India during May to September, 2008-09. The experiment was laid out in a factorial randomized block design with three replications and two main treatments i.e. hybrid $\mathrm{Bt} \mathrm{RCH}-2$ and Non-Bt $\mathrm{RCH}-2$ and nine sub treatments with different fertilizer doses i.e. 50\% recommended dose of fertilizer (RDF), 75\% RDF, $100 \%$ RDF, $125 \%$ RDF, $150 \%$ RDF, $100 \%$ RDF $+2 \%$ DAP spray, $100 \%$ RDF $+1 \%$ $\mathrm{MgSO}_{4}$ and $100 \% \mathrm{RDF}+1 \% \mathrm{KNO}_{3}$. The non-Bt cotton hybrid showed pronounced effect on growth parameters than Bt cotton hybrid. The treatment $100 \% \mathrm{RDF}$ at square and flowering recorded significant effects on biochemical parameters (Chlorophyll $\mathrm{N}, \mathrm{P}, \mathrm{K}, \mathrm{Mg}$ and $\mathrm{Fe}$ content), which was maximum in non-Bt hybrid as compared to Bt cotton hybrid. At boll development stage, treatment $100 \% \mathrm{RDF}+1 \% \mathrm{MgSO}_{4}$ was found to be the best for highest chlorophyll content in non-Bt than Bt cotton. The nutrient concentration in leaf was higher at square formation and goes on reducing as plant growth proceeded. The application $100 \%$ RDF along with three foliar sprays of $1 \% \mathrm{KNO}_{3}$ or $1 \% \mathrm{MgSO}_{4}$ or $2 \%$ DAP was found minimum intensity of reddening of leaves and increased yield of cotton.
\end{abstract}

\section{Introduction}

Cotton is an immensely important crop for the sustainable economy of India and livelihood of the Indian farming community. It is cultivated in about 33.9 mha across the world and in about 11.9 mha in the country (CICR, 2014). India accounts for about $32 \%$ of the global cotton area and currently ranking second after China. The production increased from a meager 2.3 m bales (170 kg lint bale $\left.\mathrm{e}^{-1}\right)$ in 1947-48 to a previous record production of $17.6 \mathrm{~m}$ bales in 1996-97 and an all time highest record of $37.5 \mathrm{~m}$ bales during 2013-14 (CICR,2014). Considering this importance of cotton crop different attempts have been made to boost up it's production. To grow the $\mathrm{Bt}$ cotton is one of the major attempt which is now a days following everywhere in India. Though the area under the Bt cotton is substantial but productivity is not of its full potential and considerable reduction in yield of cotton is due to decreasing soil fertility especially micronutrients, imbalanced use of fertilizer application and decreasing soil quality could be one of the reasons for the yield decline. Usually, a balanced optimum nutrient supply ensures optimum growth and ensures plant resistance which leads to depletion of nutrient and minimizing long term mining (Prasad et al., 2005). The nutrients are more important because in Bt cotton synchronized boll development altered the source-sink relationship due to rapid translocation of saccharides and nutrients from leaves to the developing bolls (Hebbar et al., 2007). To overcome these constraints, additional nutrition through foliar feeding is required over and above the normal fertilizer recommendation. Brar et al. (2008) opined that foliar application of water soluble complex fertilizers will act as a source of all major and micro nutrients, which helps in increasing the seed cotton yield. Foliar application of nutrients is highly beneficial, as crop benefits are achieved when the roots are unable to meet the nutrient requirement of the crop at a critical stage Foliar applications of K, especially late in the season when soil application may not be feasible or 
effective, correct the deficiency quickly and efficiently. Brar et al. (2008) reported improvement in seed cotton yield with foliar application of potassium nitrate, irrespective of the soil status and soil applied K fertilizers. Various foliar fertilizers are available that vary in the concentration of nutrients, but the studies on their comparative usefulness for cotton are lacking. In view to above, the present investigation was undertaken to study the effect of fertilizer levels and foliar application on morpho physiological, nutrient content, leaf reddening and yield in Bt and non-Bt cotton.

\section{Materials and Methods}

The field experiment was conducted at Cotton Improvement Project Farm, Mahatma Phule Krishi Vidyapeeth, Rahuri, Maharashtra, India during May to September, 2008-09. The soil of experiment plot was montomorillonitic Typic Haplusterts, deep black with slightly alkaline in reaction $\mathrm{pH}(1: 2.5) 7.8$, electrical conductivity $\left(\mathrm{dS} \mathrm{m}^{-1}\right) \quad 0.36$, Organic carbon (\%) 0.58 , $\mathrm{CaCO}_{3}(\%) 11.20$, Available nutrients $\left(\mathrm{kg} \mathrm{ha}^{-1}\right) \mathrm{N} 244.50$, P 12.90, K 526.40, Fe 4.9, Mn 8.0, Zn 0.4 and $\mathrm{Cu} 2.2$ (ppm). The experiment was laid out in a factorial randomized block design with three replications and two main treatments i.e. hybrid Bt RCH-2 and Non-Bt RCH-2 and nine sub treatments with different fertilizer doses i.e. control $\left(\mathrm{F}_{1}\right) \mathrm{O} \%$ recommended dose of fertilizer (RDF) $50 \% \mathrm{RDF}\left(\mathrm{F}_{2}\right), 75 \% \mathrm{RDF}\left(\mathrm{F}_{3}\right), 100 \% \mathrm{RDF}$ $\left(\mathrm{F}_{4}\right), 125 \% \operatorname{RDF}\left(\mathrm{F}_{5}\right), 150 \% \mathrm{RDF}\left(\mathrm{F}_{6}\right), 100 \% \mathrm{RDF}+2 \% \mathrm{DAP}$ spray $\left(\mathrm{F}_{7}\right), 100 \% \mathrm{RDF}+1 \% \mathrm{MgSO}_{4}\left(\mathrm{~F}_{8}\right)$, and $100 \% \mathrm{RDF}+1 \%$ $\mathrm{KNO}_{3}\left(\mathrm{~F}_{9}\right)$. The common RDF for Bt as well as non-Bt was $100 \mathrm{~N}, 50 \mathrm{P}_{2} \mathrm{O}_{5}$ and $50 \mathrm{~K}_{2} \mathrm{O} \mathrm{kg} \mathrm{ha-1}$. Uniform $10 \mathrm{t} \mathrm{ha}^{-1} \mathrm{FYM}$ dose was applied to all nine treatments including control. Total three sprays of nutrients were given in treatments $\mathrm{F}_{7}, \mathrm{~F}_{8}$ and $\mathrm{F}_{9}$, $1^{\text {st }}$ at boll development stage and further two sprays at 15 days interval thereafter. The recommended packages of practices were carried out. The nitrogen, phosphorus and potassium were applied through urea, single super phosphate and muriate of potash respectively as per recommended dose $50 \%$ of nitrogen and full dose of $\mathrm{P}_{2} \mathrm{O}_{5}$ and $\mathrm{K}_{2} \mathrm{O}\left(50: 50: 50 \mathrm{~N}: \mathrm{P}_{2} \mathrm{O}_{5}: \mathrm{K}_{2} \mathrm{O} \mathrm{kg} \mathrm{ha}{ }^{-1}\right)$ was applied at the time of sowing and the remaining nitrogen was applied in two split doses. The morphological observations viz.; plant height, percentage of leaf area affected with leaf reddening (\%) and total dry matter per plant were recorded at square formation (45 days after sowing), flowering ( 65 days after sowing) and boll development stages (105 days after sowing). The seed cotton from each net plot was picked by hand in three time and weighed separately at each picking and total yield $\left(\mathrm{kg} \mathrm{ha}^{-1}\right)$ was work out. Plot wise data on plant, nutrient content and yield etc. was subjected to statistical analysis by statistical method (Panse and Sukhatme, 1985). The plant samples also collected at square formation, flowering and boll development stages and prepared for laboratory analysis after drying in an oven at $70{ }^{\circ} \mathrm{C}$ and plant extract was prepared and analyzed for total $\mathrm{N}$ by micro-Kjeldahl method in $\mathrm{H}_{2} \mathrm{SO}_{4}: \mathrm{H}_{2} \mathrm{O}_{2}$ (1:1) digestion (Parkinson and Allen, 1975), total $\mathrm{P}$ by vanadomolybdate yellow color method in nitric acid $\mathrm{H}_{2} \mathrm{SO}_{4}: \mathrm{HClO}_{4}: \mathrm{HNO}_{3}$ (1:4:10) digestion (Jackson, 1973), total $\mathrm{K}$ on flame photometer in $\mathrm{H}_{2} \mathrm{SO}_{4}: \mathrm{HClO}_{4}: \mathrm{HNO}_{3}(1: 4: 10)$ (Chapman and Pratt, 1961) and Mg (Zoroski and Bureau, 1977). The chlorophyll content in leaves was estimated by colorimetric method extraction with $80 \%$ acetone (Sadasivam and Manickam,1992)

\section{Results and Discussion}

\subsection{Effect of fertilizer levels and nutrient sprays on morphological parameters}

\subsubsection{Plant height $(\mathrm{cm})$ and total dry matter per plant}

The non-Bt hybrid recorded significantly higher plant height and as compared to Bt hybrid and at square formation, boll formation and boll development stages, respectively (Table 1 and 2). This might be due to that Bt cotton contain Cry $1 \mathrm{Ac}$ gene and non-Bt cotton has more vegetative growth as compared to Bt. The application of $100 \% \mathrm{RDF}+2 \% \mathrm{DAP}$ spray recorded significantly maximum plant height $(35.90 \mathrm{~cm})$ and which was at par with $100 \% \mathrm{RDF}+1 \% \mathrm{KNO}_{3}(35.80 \mathrm{~cm})$ and it was significantly superior over all other treatments at square formation stage. Similar trend was observed at flowering. At boll development stage, the treatment $100 \% \mathrm{RDF}+2 \% \mathrm{DAP}$ spray showed significant increase in plant height $(104.74 \mathrm{~cm})$ over all other treatments tested. The reason for increase in growth components might be due to additional application of macro nutrients ( $\mathrm{N}, \mathrm{P}$ and $\mathrm{K}$ ) which might have increased the photosynthetic activity, enzyme activity and other biochemical process. The application of $100 \% \mathrm{RDF}+1 \% \mathrm{KNO}_{3}$ spray recorded maximum dry matter plant ${ }^{-1}$ at all the three growth stages viz., square formation, flowering and boll development stages, however, it was at par with $100 \% \mathrm{RDF}+1 \% \mathrm{MgSO}_{4}$ $(19.08 \mathrm{~g})$ at square formation stage, $100 \% \mathrm{RDF}+1 \% \mathrm{MgSO}_{4}$ (73.52 and $277.22 \mathrm{~g}$ ), 100\% RDF+2\% DAP spray (72.47 and $272.57 \mathrm{~g}$ ) and $150 \% \operatorname{RDF}(70.53$ and $271.75 \mathrm{~g})$ at flowering and boll development stages. Similar effects and observations were found by Pagare (2007). The soil application of $\mathrm{MgSO}_{4}(25$ $\left.\mathrm{kg} \mathrm{ha}^{-1}\right)+3$ foliar sprays of $1 \% \mathrm{MgSO}_{4}$ and 1\% 19:19:19 water soluble fertilizer at 70, 90 and 110 DAS along with RDF (100: 50: $\left.50 \mathrm{~kg} \mathrm{NPK} \mathrm{ha}^{-1}\right)+$ FYM $\left(10 \mathrm{t} \mathrm{ha}^{-1}\right)$ recorded significantly higher plant height and total dry matter production of cotton as compared to other nutritional treatments (Shivamurthy and Biradar, 2014). Pettigrew (2008) reported that potassium deficiency can lead to a reduction in both number of leaves and area of individual leaves. The interaction between Bt/non-Bt cotton hybrid and fertilizers doses was found statistically significant at boll formation and boll development stages 
for plant height and at boll development stage.

3.2. Effect of fertilizer levels and nutrient sprays on biochemical parameters

\subsubsection{Total chlorophyll content of affected (red) leaf}

The chlorophyll content of leaves decreased from square formation to boll development stages. Chlorophyll content in case of affected (red) leaves in non-Bt cotton was recorded maximum as compared to Bt cotton and it was progressively decreased from square formation to boll development stages
(Table 3). Further, it was also observed that chlorophyll content of non-Bt hybrid was maximum as compared to $\mathrm{Bt}$ hybrid at all the growth stages. The $100 \%$ RDF was recorded maximum chlorophyll content $\left(1.27 \mathrm{mg} \mathrm{g}^{-1}\right)$ and $100 \% \mathrm{RDF}+1 \% \mathrm{MgSO}_{4}$ (1.26), 100\% RDF+1\% $\mathrm{KNO}_{3}(1.25)$ and $100 \% \mathrm{RDF}+2 \%$ DAP spray (1.25) remained at par with $100 \%$ RDF and it was significantly superior over the all other treatments tested at square formation in affected leaves (Table 3). The treatments $100 \% \mathrm{RDF}+2 \% \mathrm{DAP}$ spray , $100 \% \mathrm{RDF}+1 \%$ $\mathrm{MgSO}_{4}$ and $100 \% \mathrm{RDF}+1 \% \mathrm{KNO}_{3}$ were at par with each other

\begin{tabular}{|c|c|c|c|c|c|c|c|c|c|}
\hline \multirow[t]{2}{*}{ Treatments } & \multicolumn{3}{|c|}{$\begin{array}{c}\text { Square formation } \\
\text { (45 Days after sowing) }\end{array}$} & \multicolumn{3}{|c|}{$\begin{array}{c}\text { Flowering } \\
\text { (65 Days after sowing) }\end{array}$} & \multicolumn{3}{|c|}{$\begin{array}{c}\text { Boll development } \\
\text { (105 Days after sowing) }\end{array}$} \\
\hline & $\mathrm{H}_{1}: \mathrm{Bt}$ & $\mathrm{H}_{2}:$ Non-Bt & Mean & $\mathrm{H}_{1}: \mathrm{Bt}$ & $\mathrm{H}_{2}$ : Non-Bt & Mean & $\mathrm{H}_{1}: \mathrm{Bt}$ & $\mathrm{H}_{2}$ : Non-Bt & Mean \\
\hline $\mathrm{F}_{1}$ : Control & 20.33 & 22.40 & 21.37 & 28.00 & 34.29 & 31.15 & 59.67 & 68.07 & 63.87 \\
\hline $\mathrm{F}_{2}: 50 \% \mathrm{RDF}$ & 28.81 & 30.89 & 29.85 & 47.12 & 55.17 & 51.14 & 90.32 & 91.37 & 90.84 \\
\hline $\mathrm{F}_{3}: 75 \% \mathrm{RDF}$ & 30.77 & 32.08 & 31.42 & 48.41 & 56.22 & 52.32 & 91.09 & 94.08 & 92.58 \\
\hline $\mathrm{F}_{4}: 100 \% \mathrm{RDF}$ & 33.23 & 36.12 & 34.67 & 55.81 & 66.47 & 61.14 & 95.64 & 97.74 & 96.69 \\
\hline $\mathrm{F}_{5}: 125 \% \mathrm{RDF}$ & 30.88 & 32.38 & 31.63 & 50.57 & 63.03 & 59.22 & 94.73 & 96.97 & 95.85 \\
\hline $\mathrm{F}_{6}: 150 \% \mathrm{RDF}$ & 33.03 & 36.03 & 34.53 & 55.40 & 63.03 & 59.22 & 94.73 & 93.97 & 95.85 \\
\hline $\mathrm{F}_{7}: \mathrm{RDF}+2 \%$ DAP spray & 34.17 & 37.63 & 35.90 & 59.27 & 75.26 & 67.26 & 100.96 & 108.52 & 104.74 \\
\hline $\mathrm{F}_{8}: \mathrm{RDF}+1 \% \mathrm{MgSO}_{4}$ spray & 33.07 & 35.80 & 34.43 & 58.65 & 67.37 & 63.00 & 99.93 & 101.40 & 100.66 \\
\hline $\mathrm{F}_{9}: \mathrm{RDF}+1 \% \mathrm{KNO}_{3}$ spray & 37.07 & 37.53 & 35.80 & 72.93 & 66.18 & 100.37 & 104.79 & 102.58 & 102.58 \\
\hline \multirow[t]{2}{*}{ Mean } & 30.93 & 33.43 & 32.18 & 51.41 & 61.08 & 56.24 & 91.71 & 95.38 & 93.54 \\
\hline & $\mathrm{H}$ & $\mathrm{F}$ & HX F & $\mathrm{H}$ & $\mathrm{F}$ & HX F & $\mathrm{H}$ & $\mathrm{F}$ & HX F \\
\hline $\mathrm{SEm} \pm$ & 0.19 & 0.41 & 0.59 & 0.46 & 0.97 & 1.37 & 0.24 & 0.51 & 0.72 \\
\hline $\mathrm{CD}(p=0.05)$ & 0.56 & 1.19 & NS & 1.31 & 2.78 & 3.93 & 0.69 & 1.46 & 2.6 \\
\hline
\end{tabular}

H: Hybrid; F: Fertilizer; RDF: Recommended dose of fertilizer

Table 2: Effect of levels of NPK and foliar sprays of nutrients on total dry matter plant ${ }^{-1}(\mathrm{~g})$ of $\mathrm{Bt}$ and non-Bt Cotton hybrid cotton

\begin{tabular}{|c|c|c|c|c|c|c|c|c|c|}
\hline \multirow[t]{2}{*}{ Treatments } & \multicolumn{3}{|c|}{$\begin{array}{c}\text { Square formation } \\
\text { (45 Days after sowing) }\end{array}$} & \multicolumn{3}{|c|}{$\begin{array}{c}\text { Flowering } \\
\text { (65 Days after sowing) }\end{array}$} & \multicolumn{3}{|c|}{$\begin{array}{c}\text { Boll development } \\
\text { (105 Days after sowing) }\end{array}$} \\
\hline & $\mathrm{H}_{1}: \mathrm{Bt}$ & $\mathrm{H}_{2}:$ Non-Bt & Mean & $\mathrm{H}_{1}: \mathrm{Bt}$ & $\mathrm{H}_{2}:$ Non-Bt & Mean & $\mathrm{H}_{1}: \mathrm{Bt}$ & $\mathrm{H}_{2}$ : Non-Bt & Mean \\
\hline $\mathrm{F}_{1}:$ Control & 8.73 & 12.17 & 10.45 & 29.13 & 48.70 & 38.92 & 107.97 & 172.03 & 140.00 \\
\hline $\mathrm{F}_{2}: 50 \% \mathrm{RDF}$ & 13.30 & 16.71 & 15.00 & 58.92 & 65.88 & 62.40 & 155.78 & 192.89 & 174.33 \\
\hline $\mathrm{F}_{3}: 75 \% \mathrm{RDF}$ & 14.33 & 16.33 & 15.33 & 60.58 & 71.56 & 66.07 & 205.50 & 222.12 & 213.81 \\
\hline $\mathrm{F}_{4}: 100 \% \mathrm{RDF}$ & 16.86 & 19.51 & 18.19 & 66.93 & 77.50 & 72.22 & 301.02 & 282.84 & 292.02 \\
\hline $\mathrm{F}_{5}: 125 \% \mathrm{RDF}$ & 15.30 & 17.83 & 16.56 & 63.04 & 72.09 & 67.58 & 209.80 & 229.50 & 219.65 \\
\hline $\mathrm{F}_{6}: 150 \% \mathrm{RDF}$ & 16.33 & 19.33 & 17.83 & 65.87 & 75.20 & 70.53 & 263.70 & 279.80 & 271.75 \\
\hline $\mathrm{F}_{7}: \mathrm{RDF}+2 \%$ DAP spray & 17.97 & 20.20 & 19.08 & 67.13 & 79.90 & 73.52 & 273.70 & 280.73 & 277.22 \\
\hline $\mathrm{F}_{8}: \mathrm{RDF}+1 \% \mathrm{MgSO}_{4}$ spray & 18.80 & 21.37 & 20.08 & 79.60 & 80.73 & 75.17 & 296.63 & 303.65 & 286.64 \\
\hline $\mathrm{F}_{9}: \mathrm{RDF}+1 \% \mathrm{KNO}_{3}$ spray & 15.46 & 18.12 & 16.79 & 60.71 & 72.37 & 66.54 & 288.07 & 249.27 & 238.67 \\
\hline \multirow[t]{2}{*}{ Mean } & 15.46 & 18.12 & 16.79 & 60.71 & 72.37 & 66.54 & 218.07 & 249.26 & 238.67 \\
\hline & $\mathrm{H}$ & $\mathrm{F}$ & $\mathrm{H} \times \mathrm{F}$ & $\mathrm{H}$ & $\mathrm{F}$ & $\mathrm{H} \times \mathrm{F}$ & $\mathrm{H}$ & $\mathrm{F}$ & $\mathrm{H} \times \mathrm{F}$ \\
\hline $\operatorname{SEm} \pm$ & 0.19 & 0.39 & 0.56 & 0.82 & 1.74 & 2.47 & 3.01 & 6.39 & 6.04 \\
\hline $\mathrm{CD}(p=0.05)$ & 0.53 & 1.13 & NS & 2.36 & 5.01 & NS & 8.66 & 18.38 & 25.99 \\
\hline
\end{tabular}

H:Hybrid; F: Fertilizer; RDF: Recommended dose of fertilizer 
at flowering and boll development stage. Chlorophyll content was higher in plants sprayed by foliar potassium fertilizers (Chapagain and Wiesma, 2004). In respect to interaction effect between $\mathrm{Bt} /$ non-Bt with fertilizer levels found significant at boll formation stage and boll development stage. The treatments $100 \% \mathrm{RDF}+2 \% \mathrm{DAP}$ spray and $100 \% \mathrm{RDF}+1 \%$ $\mathrm{MgSO}_{4}$ to $\mathrm{Bt}$ and non-Bt cotton showed higher chlorophyll content of leaves at boll formation and boll development stage. The increase in chlorophyll content of affected leaves due to application of foliar nutrients at boll development stage indicated high requirement of nutrients by Bt cotton hybrid at boll development stage, which can be met through nutrient sprays. The total chlorophyll content was significantly higher with recommended dose of fertilizer based on soil test value with $10 \mathrm{t} \mathrm{FYM} \mathrm{ha}^{-1}$ with one spray of each of $1 \%$ and $2 \%$ Urea and $1 \% \mathrm{MgSO}_{4}$ during flowering to boll development stage (Patel et al., 2011)

\subsection{Effect of fertilizer levels and nutrient sprays on nutrient content in leaves}

\subsubsection{Nitrogen and magnesium content of affected leaves}

The leaf nitrogen and magnesium content of the Bt and nonBt hybrid decreased progressively from square formation to boll development stages. Nitrogen and magnesium content in the affected leaves in non-Bt cotton was recorded higher as compared to Bt hybrid and it was decreased from square formation to boll development stages (Table 4 and 5). The application of $100 \% \mathrm{RDF}+1 \% \mathrm{KNO}_{3}$ recorded maximum nitrogen content $(1.72 \%)$ which was at par with $100 \%$ $\mathrm{RDF}+2 \%$ DAP spray (1.68\%) at square formation. The application of $100 \% \mathrm{RDF}+1 \% \mathrm{KNO}_{3}$ showed statistically higher nitrogen content (1.63 and $1.21 \%$ ) at flowering and boll development stage, respectively. The application of $100 \%$ $\mathrm{RDF}+1 \% \mathrm{MgSO}_{4}$ recorded highest magnesium content of leaves $(1.05 \%)$ at square formation and it remained at par with $100 \% \mathrm{RDF}+2 \%$ DAP spray (1.04\%) and it was significantly superior over the all other treatments tested. The application of $100 \% \mathrm{RDF}+1 \% \mathrm{MgSO}_{4}$ showed highest magnesium content $(1.04 \%)$ at boll formation stage and boll development and it remained at par with $100 \% \mathrm{RDF}+2 \% \mathrm{DAP}$ spray $(0.77 \%)$, $100 \% \mathrm{RDF}+1 \% \mathrm{KNO}_{3}(0.77 \%), 150 \% \mathrm{RDF}(0.77 \%)$ and $100 \%$ $\mathrm{RDF}(0.76 \%)$. In respect to interaction between $\mathrm{Bt} / \mathrm{non}-\mathrm{Bt}$ with fertilizer levels found non significant at boll development stage and significant results were found at flowering. Sekhon and Singh (2013) reported that the only N and K contents of premature senesced leaves were below the sufficiency range for cotton sufficient levels of $\mathrm{P}, \mathrm{Fe}, \mathrm{Mn}, \mathrm{Zn}$ and $\mathrm{Cu}$ were observed. Though the concentrations of $\mathrm{N}$ and $\mathrm{K}$ in both the petiole and leaf blade initially improved with foliar spray, $\mathrm{N}$ content declined below the unsprayed control at later stages.

\subsubsection{Phosphorus content of leaves}

The phosphorus content of leaves was slightly increased from square formation to flowering stage, but at boll development stage it was slightly declined. Bt hybrid contain maximum percentage of phosphorus as compared to non-Bt hybrid at square formation, flowering and boll development stage, respectively. The application of $100 \% \mathrm{RDF}+2 \% \mathrm{DAP}$ spray recorded significantly maximum phosphorus content in the leaves at all three growth stages and which was at par with

Table 3: Effect of levels of NPK and foliar sprays of nutrients on total chlorophyll content of affected ( $\left.\mathrm{mg} \mathrm{g}^{-1}\right)$ of Bt and non-Bt Cotton hybrid cotton

\begin{tabular}{|c|c|c|c|c|c|c|c|c|c|}
\hline \multirow[t]{2}{*}{ Treatments } & \multicolumn{3}{|c|}{$\begin{array}{c}\text { Square formation } \\
\text { (45 Days after sowing) }\end{array}$} & \multicolumn{3}{|c|}{$\begin{array}{c}\text { Flowering } \\
\text { (65 Days after sowing) }\end{array}$} & \multicolumn{3}{|c|}{$\begin{array}{c}\text { Boll development } \\
\text { (105 Days after sowing) }\end{array}$} \\
\hline & $\mathrm{H}_{1}: \mathrm{Bt}$ & $\mathrm{H}_{2}:$ Non-Bt & Mean & $\mathrm{H}_{1}: \mathrm{Bt}$ & $\mathrm{H}_{2}:$ Non-Bt & Mean & $\mathrm{H}_{1}: \mathrm{Bt}$ & $\mathrm{H}_{2}:$ Non-Bt & Mean \\
\hline $\mathrm{F}_{1}$ : Control & 1.10 & 1.18 & 1.14 & 0.57 & 0.80 & 0.68 & 0.41 & 0.52 & 0.46 \\
\hline $\mathrm{F}_{2}: 50 \% \mathrm{RDF}$ & 1.16 & 1.19 & 1.18 & 0.93 & 1.00 & 0.97 & 0.58 & 0.65 & 0.62 \\
\hline $\mathrm{F}_{3}: 75 \% \mathrm{RDF}$ & 1.16 & 1.20 & 1.18 & 0.97 & 1.02 & 0.99 & 0.68 & 0.74 & 0.71 \\
\hline $\mathrm{F}_{4}: 100 \% \mathrm{RDF}$ & 1.26 & 1.26 & 1.27 & 1.03 & 1.06 & 1.05 & 0.85 & 0.91 & 0.88 \\
\hline $\mathrm{F}_{5}: 125 \% \mathrm{RDF}$ & 1.17 & 1.21 & 1.19 & 0.97 & 1.02 & 0.99 & 0.79 & 0.75 & 0.70 \\
\hline $\mathrm{F}_{6}: 150 \% \mathrm{RDF}$ & 1.19 & 1.24 & 1.22 & 1.00 & 1.06 & 1.04 & 0.67 & 0.86 & 0.67 \\
\hline $\mathrm{F}_{7}: \mathrm{RDF}+2 \%$ DAP spray & 1.24 & 1.26 & 1.25 & 1.01 & 1.08 & 1.05 & 1.15 & 1.13 & 1.14 \\
\hline $\mathrm{F}_{8}: \mathrm{RDF}+1 \% \mathrm{MgSO}_{4}$ spray & 1.25 & 1.27 & 1.26 & 1.01 & 1.08 & 1.05 & 1.17 & 1.15 & 1.17 \\
\hline $\mathrm{F}_{9}: \mathrm{RDF}+1 \% \mathrm{KNO}_{3}$ spray & 1.23 & 1.27 & 1.25 & 1.00 & 1.06 & 1.03 & 1.17 & 1.16 & 1.16 \\
\hline \multirow[t]{2}{*}{ Mean } & 1.19 & 1.23 & 1.22 & 0.95 & 1.02 & 0.98 & 0.83 & 0.85 & 0.84 \\
\hline & $\mathrm{H}$ & $\mathrm{F}$ & HX F & $\mathrm{H}$ & $\mathrm{F}$ & HX F & $\mathrm{H}$ & $\mathrm{F}$ & HX F \\
\hline $\operatorname{SEm} \pm$ & 0.005 & 0.011 & 0.016 & 0.005 & 0.011 & 0.015 & 0.004 & 0.009 & 0.013 \\
\hline $\mathrm{CD}(p=0.05)$ & 0.01 & 0.03 & N.S & 0.01 & 0.03 & 0.04 & 0.01 & 0.03 & 0.04 \\
\hline
\end{tabular}

H: Hybrid; F: Fertilizer; RDF: Recommended dose of fertilizer 
$100 \% \mathrm{RDF}+1 \% \mathrm{MgSO}_{4}$ at square and flowering stage, however application of $100 \% \mathrm{RDF}+2 \%$ DAP spray was at par with $100 \% \operatorname{RDF}(0.87 \%)$ and statistically significant over all other treatments at boll development. The treatment $100 \% \mathrm{RDF}+2 \%$ DAP spray to Bt and non-Bt cotton (0.89\%) were recorded higher phosphorus content.

\subsubsection{Potassium and iron content of leaves}

The potassium and iron content of leaves progressively decreases from square formation to boll development stages. Non-Bt hybrid recorded maximum potassium and iron content in leaves and as compared to Bt hybrid at square formation, flowering and boll development stage, respectively (Table 6 and 7). The application of $100 \% \mathrm{RDF}+1 \% \mathrm{KNO}_{3}$ recorded significantly higher potassium content in leaves at all three stages which was at par with $100 \% \mathrm{RDF}+2 \%$ DAP spray and it was significantly superior over the control $(2.93 \%)$. Similar observation was also recorded by Jadhao et al. (2004).
Hussein et al. (2006) found that $\mathrm{N}$ and $\mathrm{K}$ concentrations in shoots of barley plants were increased as a result of $\mathrm{K}$ application. The interaction effect between Bt cotton hybrids and fertilizer treatments were significant at boll formation and boll development stages (Table 6). The application of $100 \%$ $\mathrm{RDF}+1 \% \mathrm{KNO}_{3}$ to non-Bt cotton exhibited significantly superior potassium content at flowering and at boll development stages; however, it was at par with $100 \% \mathrm{RDF}+2 \% \mathrm{DAP}$ spray at both the stages. The application of $100 \% \mathrm{RDF}$ recorded maximum iron content in the leaves (12.13 ppm) and $100 \% \mathrm{RDF}+1 \%$ $\mathrm{MgSO}_{4}(12.11 \mathrm{ppm})$ and $100 \% \mathrm{RDF}+1 \% \mathrm{KNO}_{3}(12.09 \mathrm{ppm})$ remained at par with each other and it was significantly superior over all other treatments tested at square formation (Table 7). The application of $100 \% \mathrm{RDF}+1 \% \mathrm{MgSO}_{4}$ showed statistically significant higher Fe content at flowering (9.04 ppm) and boll development (11.59 ppm) stages over all other treatments tested. In respect to interaction between $\mathrm{Bt} /$ non-Bt with fertilizer doses was found significant at all growth stages.

\begin{tabular}{|c|c|c|c|c|c|c|c|c|c|}
\hline \multirow[t]{2}{*}{ Treatments } & \multicolumn{3}{|c|}{$\begin{array}{c}\text { Square formation } \\
\text { (45 Days after sowing) }\end{array}$} & \multicolumn{3}{|c|}{$\begin{array}{c}\text { Flowering } \\
\text { (65 Days after sowing) }\end{array}$} & \multicolumn{3}{|c|}{$\begin{array}{c}\text { Boll development } \\
\text { (105 Days after sowing) }\end{array}$} \\
\hline & $\mathrm{H}_{1}: \mathrm{Bt}$ & $\mathrm{H}_{2}:$ Non-Bt & Mean & $\mathrm{H}_{1}: \mathrm{Bt}$ & $\mathrm{H}_{2}:$ Non-Bt & Mean & $\mathrm{H}_{1}: \mathrm{Bt}$ & $\mathrm{H}_{2}$ : Non-Bt & Mean \\
\hline $\mathrm{F}_{1}:$ Control & $\begin{array}{c}1.01 \\
(5.74)\end{array}$ & $\begin{array}{c}1.24 \\
(6.38)\end{array}$ & $\begin{array}{c}1.13 \\
(6.06)\end{array}$ & $\begin{array}{c}1.01 \\
(5.79)\end{array}$ & $\begin{array}{c}1.14 \\
(6.11)\end{array}$ & $\begin{array}{c}1.07 \\
(5.92)\end{array}$ & $\begin{array}{c}0.09 \\
(1.81)\end{array}$ & $\begin{array}{c}0.17 \\
(2.25)\end{array}$ & $\begin{array}{c}0.13 \\
(2.03)\end{array}$ \\
\hline $\mathrm{F}_{2}: 50 \% \mathrm{RDF}$ & $\begin{array}{c}1.24 \\
(6.38)\end{array}$ & $\begin{array}{c}1.52 \\
(7.03)\end{array}$ & $\begin{array}{c}1.38 \\
(6.70)\end{array}$ & $\begin{array}{c}1.02 \\
(5.83)\end{array}$ & $\begin{array}{c}1.38 \\
(6.79)\end{array}$ & $\begin{array}{l}1.19 \\
(6.31)\end{array}$ & $\begin{array}{c}0.62 \\
(4.44)\end{array}$ & $\begin{array}{c}0.78 \\
(5.12)\end{array}$ & $\begin{array}{c}0.69 \\
(4.78)\end{array}$ \\
\hline $\mathrm{F}_{3}: 75 \% \mathrm{RDF}$ & $\begin{array}{c}1.44 \\
(6.95)\end{array}$ & $\begin{array}{l}1.68 \\
(7.42)\end{array}$ & $\begin{array}{c}1.56 \\
(7.18)\end{array}$ & $\begin{array}{l}1.25 \\
(6.46)\end{array}$ & $\begin{array}{l}1.45 \\
(6.87)\end{array}$ & $\begin{array}{l}1.35 \\
(6.66)\end{array}$ & $\begin{array}{c}0.87 \\
(5.44)\end{array}$ & $\begin{array}{c}1.01 \\
(5.73)\end{array}$ & $\begin{array}{c}0.94 \\
(5.59)\end{array}$ \\
\hline $\mathrm{F}_{4}: 100 \% \mathrm{RDF}$ & $\begin{array}{c}1.23 \\
(6.38)\end{array}$ & $\begin{array}{c}1.51 \\
(7.03)\end{array}$ & $\begin{array}{c}1.37 \\
(6.70)\end{array}$ & $\begin{array}{c}1.29 \\
(6.53)\end{array}$ & $\begin{array}{c}1.69 \\
(7.42)\end{array}$ & $\begin{array}{c}1.49 \\
(6.97)\end{array}$ & $\begin{array}{c}0.99 \\
(5.72)\end{array}$ & $\begin{array}{c}1.24 \\
(6.38)\end{array}$ & $\begin{array}{c}1.11 \\
(6.05)\end{array}$ \\
\hline $\mathrm{F}_{5}: 125 \% \mathrm{RDF}$ & $\begin{array}{c}1.18 \\
(6.20)\end{array}$ & $\begin{array}{c}1.69 \\
(7.42)\end{array}$ & $\begin{array}{l}1.53 \\
(6.80)\end{array}$ & $\begin{array}{l}1.27 \\
(6.38)\end{array}$ & $\begin{array}{c}1.51 \\
(7.03)\end{array}$ & $\begin{array}{l}1.39 \\
(6.70)\end{array}$ & $\begin{array}{c}0.87 \\
(5.54)\end{array}$ & $\begin{array}{l}1.03 \\
(5.74)\end{array}$ & $\begin{array}{c}0.95 \\
(5.64)\end{array}$ \\
\hline $\mathrm{F}_{6}: 150 \% \mathrm{RDF}$ & $\begin{array}{c}1.41 \\
(6.80)\end{array}$ & $\begin{array}{l}1.52 \\
(7.03)\end{array}$ & $\begin{array}{c}1.47 \\
(6.91)\end{array}$ & $\begin{array}{c}1.44 \\
(6.88)\end{array}$ & $\begin{array}{c}1.51 \\
(7.03)\end{array}$ & $\begin{array}{l}1.47 \\
(6.95)\end{array}$ & $\begin{array}{c}0.96 \\
(5.54)\end{array}$ & $\begin{array}{c}1.26 \\
(6.38)\end{array}$ & $\begin{array}{c}1.11 \\
(5.96)\end{array}$ \\
\hline $\mathrm{F}_{7}: \mathrm{RDF}+2 \%$ DAP spray & $\begin{array}{c}1.55 \\
(7.17)\end{array}$ & $\begin{array}{c}1.82 \\
(7.71)\end{array}$ & $\begin{array}{c}1.68 \\
(7.41)\end{array}$ & $\begin{array}{c}1.52 \\
(7.03)\end{array}$ & $\begin{array}{c}1.51 \\
(7.03)\end{array}$ & $\begin{array}{c}1.52 \\
(7.03)\end{array}$ & $\begin{array}{c}1.05 \\
(5.93)\end{array}$ & $\begin{array}{c}1.18 \\
(6.20)\end{array}$ & $\begin{array}{c}1.72 \\
(6.06)\end{array}$ \\
\hline $\mathrm{F}_{8}: \mathrm{RDF}+1 \% \mathrm{MgSO}_{4}$ spray & $\begin{array}{c}1.51 \\
(7.03)\end{array}$ & $\begin{array}{c}1.79 \\
(7.71)\end{array}$ & $\begin{array}{c}1.65 \\
(7.37)\end{array}$ & $\begin{array}{c}1.51 \\
(7.03)\end{array}$ & $\begin{array}{c}1.52 \\
(7.03)\end{array}$ & $\begin{array}{c}1.51 \\
(7.03)\end{array}$ & $\begin{array}{c}1.01 \\
(5.83)\end{array}$ & $\begin{array}{c}1.08 \\
(5.83)\end{array}$ & $\begin{array}{c}1.05 \\
(5.83)\end{array}$ \\
\hline $\mathrm{F}_{9}: \mathrm{RDF}+1 \% \mathrm{KNO}_{3}$ spray & $\begin{array}{c}1.52 \\
(7.03)\end{array}$ & $\begin{array}{c}1.92 \\
(7.92)\end{array}$ & $\begin{array}{c}1.72 \\
(7.47)\end{array}$ & $\begin{array}{c}1.58 \\
(7.11)\end{array}$ & $\begin{array}{c}1.69 \\
(7.26)\end{array}$ & $\begin{array}{c}1.63 \\
(7.19)\end{array}$ & $\begin{array}{c}1.14 \\
(5.93)\end{array}$ & $\begin{array}{c}1.28 \\
(6.46)\end{array}$ & $\begin{array}{c}1.21 \\
(6.19)\end{array}$ \\
\hline Mean & $\begin{array}{c}1.34 \\
(6.62)\end{array}$ & $\begin{array}{c}1.63 \\
(7.29)\end{array}$ & $\begin{array}{c}1.49 \\
(6.96)\end{array}$ & $\begin{array}{c}1.32 \\
(6.55)\end{array}$ & $\begin{array}{c}1.49 \\
(6.95)\end{array}$ & $\begin{array}{c}1.40 \\
(6.75)\end{array}$ & $\begin{array}{c}0.84 \\
(5.13)\end{array}$ & $\begin{array}{c}1.00 \\
(5.57)\end{array}$ & $\begin{array}{c}0.92 \\
(5.35)\end{array}$ \\
\hline & $\mathrm{H}$ & $\mathrm{F}$ & HX F & $\mathrm{H}$ & F & HX F & $\mathrm{H}$ & F & HX F \\
\hline $\mathrm{SEm} \pm$ & $\begin{array}{l}0.008 \\
(0.02)\end{array}$ & $\begin{array}{l}0.017 \\
(0.04)\end{array}$ & $\begin{array}{l}0.025 \\
(0.05)\end{array}$ & $\begin{array}{c}0.01 \\
(0.04)\end{array}$ & $\begin{array}{c}0.03 \\
(0.08)\end{array}$ & $\begin{array}{c}0.04 \\
(0.011)\end{array}$ & $\begin{array}{c}0.01 \\
(0.05)\end{array}$ & $\begin{array}{c}0.03 \\
(0.10)\end{array}$ & $\begin{array}{c}0.04 \\
(0.14)\end{array}$ \\
\hline $\mathrm{CD}(p=0.05)$ & $\begin{array}{l}0.024 \\
(0.05)\end{array}$ & $\begin{array}{c}0.05 \\
(0.10)\end{array}$ & $\begin{array}{l}0.071 \\
(0.15)\end{array}$ & $\begin{array}{l}0.042 \\
(0.11)\end{array}$ & $\begin{array}{l}0.089 \\
(0.23)\end{array}$ & $\begin{array}{c}0.13 \\
(0.33)\end{array}$ & $\begin{array}{c}0.04 \\
(0.014)\end{array}$ & $\begin{array}{c}0.08 \\
(0.029)\end{array}$ & $\begin{array}{c}\text { N.S } \\
\text { (N.S) }\end{array}$ \\
\hline
\end{tabular}

H:Hybrid; F: Fertilizer; RDF: Recommended dose of fertilizer; Figures in parenthesis indicates arcsine values 
The application of $100 \% \mathrm{RDF}+2 \% \mathrm{DAP}$ spray to non-Bt cotton showed higher iron content of leaves at square formation, which was at par with $100 \% \mathrm{RDF}, 100 \% \mathrm{RDF}+1 \% \mathrm{MgSO}_{4}$ and $100 \% \mathrm{RDF}+1 \% \mathrm{KNO}_{3}$, however, the iron content of leaves at flowering and boll development stage was significantly higher in $100 \% \mathrm{RDF}+1 \% \mathrm{MgSO}_{4}$.

\subsection{Effect offertilizer levels and nutrient sprays on percentage} of plant affected with reddening of leaves

The percentage of plants affected with reddening was observed maximum in Bt hybrid as compared to non-Bt hybrid and it was increased from square formation to boll development stage in both the hybrids (Table 8). The highest percentage of reddening in Bt hybrid was observed at boll development stage (26.25\%). Bt hybrid recorded maximum reddening percentage of as compared to non-Bt hybrid at square formation, flowering and boll development stage. The higher dose of nitrogen along with phosphorus and potash may be beneficial for the control of reddening of leaves. Such type of observations also recorded by Bell et al. (2006). The percentage of plant affected with reddening of leaves was progressively increased from square formation to boll development stage. The application of $100 \%$ RDF recorded minimum percentage of plant affected with reddening at square formation and flowering stage, respectively. However, it was at par with $150 \%$ RDF, $100 \%$ $\mathrm{RDF}+2 \%$ DAP spray, $100 \% \mathrm{RDF}+1 \% \mathrm{MgSO}_{4}$ and $100 \%$ $\mathrm{RDF}+1 \% \mathrm{KNO}_{3}$ at both the development stages. Similar trend was also observed at boll development stage. The evidence of the highest reddening in control treatment than the treatments of $100 \%$ RDF and $100 \%$ RDF+foliar sprays at all the growth stages. The application of recommended dose of fertilizer based on soil test value along with one spray of each of $1 \%$ and $2 \%$ urea and $1 \% \mathrm{MgSO}_{4}$ during flowering to boll development stage significantly reduced incidence of leaf reddening in $\mathrm{Bt}$ cotton (Patel et al.2011). The interaction effect with fertilizer

Table 5: Effect of levels of NPK and foliar sprays of nutrients on magnesium content of affected (red) leaves (\%) of Bt and non-Bt Cotton

\begin{tabular}{|c|c|c|c|c|c|c|c|c|c|}
\hline \multirow[t]{2}{*}{ Treatments } & \multicolumn{3}{|c|}{$\begin{array}{c}\text { Square formation } \\
\text { (45 Days after sowing) }\end{array}$} & \multicolumn{3}{|c|}{$\begin{array}{c}\text { Flowering } \\
\text { (65 Days after sowing) }\end{array}$} & \multicolumn{3}{|c|}{$\begin{array}{c}\text { Boll development } \\
\text { (105 Days after sowing) }\end{array}$} \\
\hline & $\mathrm{H}_{1}: \mathrm{Bt}$ & $\mathrm{H}_{2}$ : Non-Bt & $\overline{\text { Mean }}$ & $\mathrm{H}_{1}: \mathrm{Bt}$ & $\mathrm{H}_{2}:$ Non-Bt & $\overline{\text { Mean }}$ & $\overline{\mathrm{H}_{1}: \mathrm{Bt}}$ & $\mathrm{H}_{2}:$ Non-Bt & Mean \\
\hline $\mathrm{F}_{1}$ : Control & $\begin{array}{c}0.79 \\
(5.13)\end{array}$ & $\begin{array}{c}0.85 \\
(5.13)\end{array}$ & $\begin{array}{c}0.82 \\
(5.43)\end{array}$ & $\begin{array}{c}0.72 \\
(4.80)\end{array}$ & $\begin{array}{c}0.81 \\
(5.13)\end{array}$ & $\begin{array}{c}0.77 \\
(4.96)\end{array}$ & $\begin{array}{c}0.42 \\
(3.63)\end{array}$ & $\begin{array}{c}0.53 \\
(4.05)\end{array}$ & $\begin{array}{c}0.48 \\
(3.84)\end{array}$ \\
\hline $\mathrm{F}_{2}: 50 \% \mathrm{RDF}$ & $\begin{array}{c}0.82 \\
(5.13)\end{array}$ & $\begin{array}{c}0.87 \\
(5.44)\end{array}$ & $\begin{array}{c}0.84 \\
(5.28)\end{array}$ & $\begin{array}{c}0.79 \\
(5.13)\end{array}$ & $\begin{array}{c}0.88 \\
(5.34)\end{array}$ & $\begin{array}{c}0.84 \\
(5.23)\end{array}$ & $\begin{array}{c}0.66 \\
(4.68)\end{array}$ & $\begin{array}{c}0.72 \\
(4.91)\end{array}$ & $\begin{array}{c}0.69 \\
(4.79)\end{array}$ \\
\hline $\mathrm{F}_{3}: 75 \% \mathrm{RDF}$ & $\begin{array}{c}0.89 \\
(5.34)\end{array}$ & $\begin{array}{c}0.95 \\
(5.54)\end{array}$ & $\begin{array}{c}0.92 \\
(5.44)\end{array}$ & $\begin{array}{c}0.82 \\
(5.13)\end{array}$ & $\begin{array}{c}0.92 \\
(5.44)\end{array}$ & $\begin{array}{c}0.87 \\
(5.28)\end{array}$ & $\begin{array}{c}0.69 \\
(4.68)\end{array}$ & $\begin{array}{c}0.77 \\
(5.13)\end{array}$ & $\begin{array}{c}0.73 \\
(4.90)\end{array}$ \\
\hline $\mathrm{F}_{4}: 100 \% \mathrm{RDF}$ & $\begin{array}{c}0.91 \\
(5.44)\end{array}$ & $\begin{array}{c}1.00 \\
(5.74)\end{array}$ & $\begin{array}{c}0.96 \\
(5.59)\end{array}$ & $\begin{array}{c}0.84 \\
(5.23)\end{array}$ & $\begin{array}{c}0.95 \\
(5.54)\end{array}$ & $\begin{array}{c}0.89 \\
(5.39)\end{array}$ & $\begin{array}{c}0.72 \\
(4.91)\end{array}$ & $\begin{array}{c}0.79 \\
(5.13)\end{array}$ & $\begin{array}{c}0.76 \\
(5.02)\end{array}$ \\
\hline $\mathrm{F}_{5}: 125 \% \mathrm{RDF}$ & $\begin{array}{c}0.86 \\
(5.34)\end{array}$ & $\begin{array}{c}0.95 \\
(5.54)\end{array}$ & $\begin{array}{c}0.91 \\
(5.44)\end{array}$ & $\begin{array}{c}0.84 \\
(5.13)\end{array}$ & $\begin{array}{c}0.94 \\
(5.44)\end{array}$ & $\begin{array}{c}0.89 \\
(5.28)\end{array}$ & $\begin{array}{c}0.71 \\
(4.80)\end{array}$ & $\begin{array}{c}0.75 \\
(4.91)\end{array}$ & $\begin{array}{c}0.73 \\
(4.85)\end{array}$ \\
\hline $\mathrm{F}_{6}: 150 \% \mathrm{RDF}$ & $\begin{array}{c}0.89 \\
(5.44)\end{array}$ & $\begin{array}{c}0.99 \\
(5.64)\end{array}$ & $\begin{array}{c}0.94 \\
(5.54)\end{array}$ & $\begin{array}{c}0.87 \\
(5.34)\end{array}$ & $\begin{array}{c}0.99 \\
(5.74)\end{array}$ & $\begin{array}{c}0.93 \\
(5.54)\end{array}$ & $\begin{array}{c}0.75 \\
(4.91)\end{array}$ & $\begin{array}{c}0.79 \\
(5.13)\end{array}$ & $\begin{array}{c}0.77 \\
(5.02)\end{array}$ \\
\hline $\mathrm{F}_{7}: \mathrm{RDF}+2 \%$ DAP spray & $\begin{array}{c}1.00 \\
(5.74)\end{array}$ & $\begin{array}{c}1.07 \\
(5.83)\end{array}$ & $\begin{array}{c}1.04 \\
(5.79)\end{array}$ & $\begin{array}{c}1.00 \\
(5.74)\end{array}$ & $\begin{array}{c}1.03 \\
(5.74)\end{array}$ & $\begin{array}{c}1.01 \\
(5.74)\end{array}$ & $\begin{array}{c}0.73 \\
(4.80)\end{array}$ & $\begin{array}{c}0.83 \\
(5.13)\end{array}$ & $\begin{array}{c}0.77 \\
(4.96)\end{array}$ \\
\hline $\mathrm{F}_{8}: \mathrm{RDF}+1 \% \mathrm{MgSO}_{4}$ spray & $\begin{array}{c}1.01 \\
5.74)\end{array}$ & $\begin{array}{c}1.08 \\
(5.93)\end{array}$ & $\begin{array}{c}1.05 \\
(5.83)\end{array}$ & $\begin{array}{c}1.01 \\
(5.74)\end{array}$ & $\begin{array}{c}1.07 \\
(5.92)\end{array}$ & $\begin{array}{c}1.04 \\
(5.83)\end{array}$ & $\begin{array}{c}0.78 \\
(5.13)\end{array}$ & $\begin{array}{c}0.86 \\
(5.23)\end{array}$ & $\begin{array}{c}0.78 \\
(4.96)\end{array}$ \\
\hline $\mathrm{F}_{9}: \mathrm{RDF}+1 \% \mathrm{KNO}_{3}$ spray & $\begin{array}{c}1.00 \\
(5.64)\end{array}$ & $\begin{array}{c}1.01 \\
(5.92)\end{array}$ & $\begin{array}{c}1.00 \\
(5.78)\end{array}$ & $\begin{array}{c}0.99 \\
(5.74)\end{array}$ & $\begin{array}{c}1.01 \\
(5.74)\end{array}$ & $\begin{array}{c}1.00 \\
(5.74)\end{array}$ & $\begin{array}{c}0.73 \\
(4.80)\end{array}$ & $\begin{array}{c}0.82 \\
(5.13)\end{array}$ & $\begin{array}{c}0.77 \\
(4.96)\end{array}$ \\
\hline Mean & $\begin{array}{c}0.91 \\
(5.44)\end{array}$ & $\begin{array}{c}0.98 \\
(5.67)\end{array}$ & $\begin{array}{c}0.94 \\
(5.55)\end{array}$ & $\begin{array}{c}0.88 \\
(5.33)\end{array}$ & $\begin{array}{c}0.96 \\
(5.55)\end{array}$ & $\begin{array}{c}0.92 \\
(5.44)\end{array}$ & $\begin{array}{c}0.69 \\
(4.70)\end{array}$ & $\begin{array}{c}0.76 \\
(4.97)\end{array}$ & $\begin{array}{c}0.73 \\
(4.84)\end{array}$ \\
\hline & $\mathrm{H}$ & $\mathrm{F}$ & HX F & $\mathrm{H}$ & $\mathrm{F}$ & $\mathrm{HX} \mathrm{F}$ & $\mathrm{H}$ & $\mathrm{F}$ & HX F \\
\hline $\mathrm{SEm} \pm$ & $\begin{array}{c}0.004 \\
(0.030)\end{array}$ & $\begin{array}{c}0.009 \\
(0.064)\end{array}$ & $\begin{array}{c}0.013 \\
(0.090)\end{array}$ & $\begin{array}{c}0.003 \\
(0.017)\end{array}$ & $\begin{array}{c}0.006 \\
(0.036)\end{array}$ & $\begin{array}{c}0.008 \\
(0.051)\end{array}$ & $\begin{array}{c}0.004 \\
(0.022)\end{array}$ & $\begin{array}{c}0.010 \\
(0.047)\end{array}$ & $\begin{array}{c}0.013 \\
(0.066)\end{array}$ \\
\hline $\mathrm{CD}(p=0.05)$ & $\begin{array}{c}0.01 \\
(0.08)\end{array}$ & $\begin{array}{c}0.03 \\
(0.18)\end{array}$ & $\begin{array}{l}\text { N.S } \\
\text { (N.S) }\end{array}$ & $\begin{array}{c}0.008 \\
(0.049)\end{array}$ & $\begin{array}{l}0.016 \\
(0.10)\end{array}$ & $\begin{array}{c}0.023 \\
(0.15)\end{array}$ & $\begin{array}{c}0.013 \\
(0.06)\end{array}$ & $\begin{array}{c}0.03 \\
(0.13)\end{array}$ & $\begin{array}{l}\text { N.S } \\
(\mathrm{N} . \mathrm{S})\end{array}$ \\
\hline
\end{tabular}

H: Hybrid; F: Fertilizer; RDF: Recommended dose of fertilizer; Figures in parenthesis indicates arcsine values 
levels and $\mathrm{Bt}$ and non-Bt cotton was non-significant at square formation and boll development stage, but it was significant at flowering stage. Among the fertilizer treatments of Bt cotton, the minimum percentage of plants affected with reddening at flowering stage was in the treatment $100 \% \mathrm{RDF}+2 \% \mathrm{DAP}$ spray, however, it was at par with $100 \% \mathrm{RDF}+1 \% \mathrm{MgSO}_{4}$ and $100 \% \mathrm{RDF}+1 \% \mathrm{KNO}_{3}$. In case of non-Bt varieties, $100 \%$ $\mathrm{RDF}+1 \% \mathrm{MgSO}_{4}$ showed minimum plant ${ }^{-1}$ reddening at flowering stage (3.67\%), however it was at par with all other treatments tested except control. It is concluded from the study that, Bt hybrids were more susceptible to reddening than non-Bt. The reddening was increased from square formation to flowering stage. Application of higher doses of NPK and foliar sprays of $2 \% \mathrm{DAP}, 1 \% \mathrm{MgSO}_{4}$ and $1 \% \mathrm{KNO}_{3}$ helped in reducing reddening of plants.

\subsection{Seed cotton yield}

The Bt hybrid recorded maximum seed cotton yield (2907 $\left.\mathrm{kg} \mathrm{ha}^{-1}\right)$ as compared to non-Bt hybrid $\left(2680 \mathrm{~kg} \mathrm{ha}^{-1}\right)($ Table
9). The application of $100 \% \mathrm{RDF}+1 \% \mathrm{MgSO}_{4}$ had given higher seed cotton yield $\left(3240 \mathrm{~kg} \mathrm{ha}^{-1}\right)$ which was at par with $100 \% \mathrm{RDF}+1 \% \mathrm{KNO}_{3}, 100 \% \mathrm{RDF}+2 \% \mathrm{DAP}$ and $150 \% \mathrm{RDF}$ $\left(3117,3042\right.$ and $2914 \mathrm{~kg} \mathrm{ha}^{-1}$, respectively). The application of $100 \% \mathrm{RDF}$ along with three foliar sprays of $1 \% \mathrm{MgSO}_{4}$ or $1 \% \mathrm{KNO}_{3}$ or $2 \%$ DAP helped in reducing reddening of leaves in cotton, which was ultimately resulted in increasing the yield of cotton, however, this effect was more pronounced under Bt cotton hybrids than non-Bt cotton hybrids. Basal application of murieta of potash (MOP) increased seed cotton yield by $19 \%$. Four foliar sprays of $\mathrm{KNO}_{3}, \mathrm{NPK}, \mathrm{MOP}$ and MOP+urea recorded yield increase in seed cotton yield of $22.8 \%, 22.4 \%$, $18.5 \%$ and $24.5 \%$, respectively over unsprayed control (Sekhon and Singh, 2013). The soil application of $\mathrm{MgSO}_{4}(25$ $\left.\mathrm{kg} \mathrm{ha}^{-1}\right)+3$ foliar sprays of $1 \% \mathrm{MgSO}_{4}$ and $1 \%$ 19:19:19 water soluble fertilizer at 70, 90 and 110 DAS along with RDF (100: 50:50 kg NPK ha $\left.{ }^{-1}\right)+F Y M\left(10 \mathrm{t} \mathrm{ha}^{-1}\right)$ recorded significantly higher seed cotton yield $\left(2781 \mathrm{~kg} \mathrm{ha}^{-1}\right)$ as compared to other

\begin{tabular}{|c|c|c|c|c|c|c|c|c|c|}
\hline \multirow[t]{2}{*}{ Treatments } & \multicolumn{3}{|c|}{$\begin{array}{c}\text { Square formation } \\
\text { (45 Days after sowing) }\end{array}$} & \multicolumn{3}{|c|}{$\begin{array}{c}\text { Flowering } \\
\text { (65 Days after sowing) }\end{array}$} & \multicolumn{3}{|c|}{$\begin{array}{c}\text { Boll development } \\
\text { (105 Days after sowing) }\end{array}$} \\
\hline & $\mathrm{H}_{1}: \mathrm{Bt}$ & $\mathrm{H}_{2}:$ Non-Bt & Mean & $\mathrm{H}_{1}: \mathrm{Bt}$ & $\mathrm{H}_{2}$ : Non-Bt & Mean & $\mathrm{H}_{1}: \mathrm{Bt}$ & $\mathrm{H}_{2}:$ Non-Bt & Mean \\
\hline $\mathrm{F}_{1}:$ Control & $\begin{array}{c}2.88 \\
(9.74)\end{array}$ & $\begin{array}{l}2.98 \\
(9.91)\end{array}$ & $\begin{array}{c}2.93 \\
(9.84)\end{array}$ & $\begin{array}{c}2.00 \\
(8.13)\end{array}$ & $\begin{array}{c}2.32 \\
(8.72)\end{array}$ & $\begin{array}{c}2.16 \\
(8.42)\end{array}$ & $\begin{array}{c}1.08 \\
(5.93)\end{array}$ & $\begin{array}{c}1.48 \\
(7.03)\end{array}$ & $\begin{array}{c}1.28 \\
(6.48)\end{array}$ \\
\hline $\mathrm{F}_{2}: 50 \% \mathrm{RDF}$ & $\begin{array}{c}2.99 \\
(9.97)\end{array}$ & $\begin{array}{c}3.07 \\
(10.08)\end{array}$ & $\begin{array}{c}3.03 \\
(10.03)\end{array}$ & $\begin{array}{c}2.22 \\
(8.53)\end{array}$ & $\begin{array}{c}2.44 \\
(8.97)\end{array}$ & $\begin{array}{l}2.33 \\
(8.75)\end{array}$ & $\begin{array}{l}1.32 \\
(6.55)\end{array}$ & $\begin{array}{c}1.59 \\
(7.27)\end{array}$ & $\begin{array}{c}1.46 \\
(6.91)\end{array}$ \\
\hline $\mathrm{F}_{3}: 75 \% \mathrm{RDF}$ & $\begin{array}{c}3.06 \\
(10.02)\end{array}$ & $\begin{array}{c}3.12 \\
(10.14)\end{array}$ & $\begin{array}{c}3.09 \\
(10.08)\end{array}$ & $\begin{array}{c}2.33 \\
(8.72)\end{array}$ & $\begin{array}{c}2.54 \\
(9.16)\end{array}$ & $\begin{array}{c}2.44 \\
(8.94)\end{array}$ & $\begin{array}{l}1.42 \\
(6.80)\end{array}$ & $\begin{array}{l}1.66 \\
(7.34)\end{array}$ & $\begin{array}{c}1.54 \\
(7.07)\end{array}$ \\
\hline $\mathrm{F}_{4}: 100 \% \mathrm{RDF}$ & $\begin{array}{c}2.13 \\
(10.14)\end{array}$ & $\begin{array}{c}3.28 \\
(10.41)\end{array}$ & $\begin{array}{c}3.20 \\
(10.28)\end{array}$ & $\begin{array}{l}2.45 \\
(8.97)\end{array}$ & $\begin{array}{l}2.83 \\
(9.63)\end{array}$ & $\begin{array}{c}2.64 \\
(9.30)\end{array}$ & $\begin{array}{l}1.58 \\
(7.19)\end{array}$ & $\begin{array}{l}1.48 \\
(7.85)\end{array}$ & $\begin{array}{c}1.73 \\
(7.72)\end{array}$ \\
\hline $\mathrm{F}_{5}: 125 \% \mathrm{RDF}$ & $\begin{array}{c}3.08 \\
(10.14)\end{array}$ & $\begin{array}{c}3.17 \\
(10.25)\end{array}$ & $\begin{array}{c}3.12 \\
(10.19)\end{array}$ & $\begin{array}{c}2.40 \\
(8.91)\end{array}$ & $\begin{array}{c}2.61 \\
(9.28)\end{array}$ & $\begin{array}{c}2.50 \\
(9.09)\end{array}$ & $\begin{array}{l}1.46 \\
(6.95)\end{array}$ & $\begin{array}{l}1.76 \\
(7.56)\end{array}$ & $\begin{array}{c}1.61 \\
(7.26)\end{array}$ \\
\hline $\mathrm{F}_{6}: 150 \% \mathrm{RDF}$ & $\begin{array}{c}3.09 \\
(10.14)\end{array}$ & $\begin{array}{c}3.22 \\
(10.30)\end{array}$ & $\begin{array}{c}3.16 \\
(10.22)\end{array}$ & $\begin{array}{c}2.44 \\
(8.97)\end{array}$ & $\begin{array}{l}2.75 \\
(9.52)\end{array}$ & $\begin{array}{c}2.59 \\
(9.24)\end{array}$ & $\begin{array}{c}1.50 \\
(7.03)\end{array}$ & $\begin{array}{c}1.82 \\
(7.71)\end{array}$ & $\begin{array}{c}1.66 \\
(7.37)\end{array}$ \\
\hline $\mathrm{F}_{7}: \mathrm{RDF}+2 \%$ DAP spray & $\begin{array}{c}3.16 \\
(10.19)\end{array}$ & $\begin{array}{c}3.31 \\
(10.47)\end{array}$ & $\begin{array}{c}3.23 \\
(10.33)\end{array}$ & $\begin{array}{c}2.51 \\
(9.10)\end{array}$ & $\begin{array}{c}2.94 \\
(9.86)\end{array}$ & $\begin{array}{c}2.73 \\
(9.48)\end{array}$ & $\begin{array}{c}1.79 \\
(7.71)\end{array}$ & $\begin{array}{c}1.93 \\
(7.92)\end{array}$ & $\begin{array}{c}1.86 \\
(7.81)\end{array}$ \\
\hline $\mathrm{F}_{8}: \mathrm{RDF}+1 \% \mathrm{MgSO}_{4}$ spray & $\begin{array}{c}3.07 \\
(10.0)\end{array}$ & $\begin{array}{c}3.24 \\
(10.36)\end{array}$ & $\begin{array}{c}3.16 \\
(10.22)\end{array}$ & $\begin{array}{c}2.44 \\
(8.97)\end{array}$ & $\begin{array}{c}2.87 \\
(9.69)\end{array}$ & $\begin{array}{c}2.65 \\
(9.33)\end{array}$ & $\begin{array}{c}1.71 \\
(7.49)\end{array}$ & $\begin{array}{c}1.90 \\
(7.92)\end{array}$ & $\begin{array}{c}1.81 \\
(7.70)\end{array}$ \\
\hline $\mathrm{F}_{9}: \mathrm{RDF}+1 \% \mathrm{KNO}_{3}$ spray & $\begin{array}{c}3.18 \\
(10.25)\end{array}$ & $\begin{array}{c}3.33 \\
(10.47)\end{array}$ & $\begin{array}{c}2.25 \\
(10.36)\end{array}$ & $\begin{array}{c}2.53 \\
(9.10)\end{array}$ & $\begin{array}{c}2.96 \\
(9.86)\end{array}$ & $\begin{array}{c}2.47 \\
(9.88)\end{array}$ & $\begin{array}{c}1.82 \\
(7.71)\end{array}$ & $\begin{array}{c}1.95 \\
(7.92)\end{array}$ & $\begin{array}{c}1.81 \\
(7.70)\end{array}$ \\
\hline Mean & $\begin{array}{c}3.07 \\
(10.07)\end{array}$ & $\begin{array}{c}3.19 \\
(10.27)\end{array}$ & $\begin{array}{c}3.13 \\
(10.17)\end{array}$ & $\begin{array}{c}2.37 \\
(8.82)\end{array}$ & $\begin{array}{c}2.69 \\
(9.41)\end{array}$ & $\begin{array}{c}2.53 \\
(9.12)\end{array}$ & $\begin{array}{c}1.52 \\
(7.04)\end{array}$ & $\begin{array}{c}1.77 \\
(7.62)\end{array}$ & $\begin{array}{c}1.65 \\
(7.33)\end{array}$ \\
\hline & $\mathrm{H}$ & $\mathrm{F}$ & $\mathrm{HX} \mathrm{F}$ & $\mathrm{H}$ & $\mathrm{F}$ & HX F & $\mathrm{H}$ & $\mathrm{F}$ & HX F \\
\hline SEm \pm & $\begin{array}{c}0.004 \\
(0.014)\end{array}$ & $\begin{array}{l}0.009 \\
(0.29)\end{array}$ & $\begin{array}{c}0.013 \\
(0.041)\end{array}$ & $\begin{array}{l}0.007 \\
(0.01)\end{array}$ & $\begin{array}{c}0.015 \\
(0.013)\end{array}$ & $\begin{array}{l}0.021 \\
(0.04)\end{array}$ & $\begin{array}{c}0.005 \\
(0.002)\end{array}$ & $\begin{array}{l}0.010 \\
(0.03)\end{array}$ & $\begin{array}{l}0.014 \\
(0.05)\end{array}$ \\
\hline $\mathrm{CD}(p=0.05)$ & $\begin{array}{c}0.012 \\
(0.04)\end{array}$ & $\begin{array}{l}0.026 \\
(0.08)\end{array}$ & $\begin{array}{l}0.037 \\
\text { (N.S) }\end{array}$ & $\begin{array}{l}0.020 \\
(0.04)\end{array}$ & $\begin{array}{c}0.04 \\
(0.09)\end{array}$ & $\begin{array}{c}0.06 \\
(0.012)\end{array}$ & $\begin{array}{l}0.013 \\
(0.05)\end{array}$ & $\begin{array}{l}0.028 \\
(0.09)\end{array}$ & $\begin{array}{l}0.039 \\
(0.14)\end{array}$ \\
\hline
\end{tabular}

H: Hybrid; F: Fertilizer; RDF: Recommended dose of fertilizer; Figures in parenthesis indicates arcsine values 


\begin{tabular}{|c|c|c|c|c|c|c|c|c|c|}
\hline \multirow[t]{2}{*}{ Treatments } & \multicolumn{3}{|c|}{$\begin{array}{c}\text { Square formation } \\
\text { (45 Days after sowing) }\end{array}$} & \multicolumn{3}{|c|}{$\begin{array}{c}\text { Flowering } \\
\text { (65 Days after sowing) }\end{array}$} & \multicolumn{3}{|c|}{$\begin{array}{c}\text { Boll development } \\
\text { (105 Days after sowing) }\end{array}$} \\
\hline & $\mathrm{H}_{1}: \mathrm{Bt}$ & $\mathrm{H}_{2}$ : Non-Bt & Mean & $\mathrm{H}_{1}: \mathrm{Bt}$ & $\mathrm{H}_{2}:$ Non-Bt & Mean & $\mathrm{H}_{1}: \mathrm{Bt}$ & $\mathrm{H}_{2}$ : Non-Bt & Mean \\
\hline $\mathrm{F}_{1}$ : Control & 11.45 & 11.62 & 11.53 & 15.72 & 6.01 & 5.87 & 4.82 & 5.26 & 5.04 \\
\hline $\mathrm{F}_{2}: 50 \% \mathrm{RDF}$ & 11.59 & 11.83 & 11.71 & 7.87 & 8.24 & 8.04 & 5.31 & 5.81 & 5.65 \\
\hline $\mathrm{F}_{3}: 75 \% \mathrm{RDF}$ & 11.64 & 11.97 & 11.81 & 8.11 & 8.41 & 8.26 & 5.54 & 6.17 & 5.85 \\
\hline $\mathrm{F}_{4}: 100 \% \mathrm{RDF}$ & 12.07 & 12.19 & 12.13 & 8.60 & 8.74 & 8.67 & 8.01 & 10.22 & 9.11 \\
\hline $\mathrm{F}_{5}: 125 \% \mathrm{RDF}$ & 11.70 & 12.05 & 11.88 & 8.26 & 8.41 & 8.33 & 5.82 & 6.64 & 6.23 \\
\hline $\mathrm{F}_{6}: 150 \% \mathrm{RDF}$ & 11.87 & 12.11 & 11.19 & 8.54 & 8.62 & 8.58 & 6.01 & 6.94 & 6.48 \\
\hline $\mathrm{F}_{7}: \mathrm{RDF}+2 \% \mathrm{DAP}$ spray & 12.00 & 12.19 & 12.00 & 8.89 & 9.11 & 9.00 & 8.44 & 10.72 & 9.58 \\
\hline $\mathrm{F}_{8}: \mathrm{RDF}+1 \% \mathrm{MgSO}_{4}$ spray & 12.07 & 12.16 & 12.11 & 8.92 & 19.16 & 9.04 & 10.37 & 12.81 & 11.59 \\
\hline $\mathrm{F}_{9}: \mathrm{RDF}+1 \% \mathrm{KNO}_{3}$ spray & 12.03 & 12.15 & 12.09 & 8.81 & 9.03 & 8.92 & 7.41 & 9.51 & 8.46 \\
\hline \multirow[t]{2}{*}{ Mean } & 11.83 & 72.03 & 11.93 & 8.19 & 8.41 & 8.30 & 6.86 & 8.23 & 7.55 \\
\hline & $\mathrm{H}$ & $\mathrm{F}$ & H X F & $\mathrm{H}$ & $\mathrm{F}$ & $\mathrm{HX} \mathrm{F}$ & $\mathrm{H}$ & $\mathrm{F}$ & $\mathrm{H} X \mathrm{~F}$ \\
\hline $\mathrm{SEm} \pm$ & 0.01 & 0.02 & 0.03 & 0.005 & 0.010 & 0.015 & 0.004 & 0.009 & 0.013 \\
\hline $\mathrm{CD}(p=0.05)$ & 0.03 & 0.06 & 0.08 & 0.01 & 0.03 & 0.004 & 0.01 & 0.03 & 0.04 \\
\hline
\end{tabular}

H:Hybrid F: Fertilizer RDF: Recommended dose of fertilizer

Table 8: Effect of levels of NPK and foliar sprays of nutrients on percentage of plant affected with reddening of leaves of Bt and nonBt Cotton

\begin{tabular}{|c|c|c|c|c|c|c|c|c|c|}
\hline \multirow[t]{2}{*}{ Treatments } & \multicolumn{3}{|c|}{$\begin{array}{c}\text { Square formation } \\
\text { (45 Days after sowing) }\end{array}$} & \multicolumn{3}{|c|}{$\begin{array}{c}\text { Flowering } \\
\text { (65 Days after sowing) }\end{array}$} & \multicolumn{3}{|c|}{$\begin{array}{c}\text { Boll development } \\
\text { (105 Days after sowing) }\end{array}$} \\
\hline & $\mathrm{H}_{1}: \mathrm{Bt}$ & $\mathrm{H}_{2}:$ Non-Bt & Mean & $\overline{\mathrm{H}_{1}: \mathrm{Bt}}$ & $\mathrm{H}_{2}$ : Non-Bt & Mean & $\overline{\mathrm{H}_{1}: \mathrm{Bt}}$ & $\mathrm{H}_{2}:$ Non-Bt & Mean \\
\hline $\mathrm{F}_{1}:$ Control & $\begin{array}{c}6.97 \\
(15.34)\end{array}$ & $\begin{array}{c}4.45 \\
(12.11)\end{array}$ & $\begin{array}{c}5.71 \\
(13.81)\end{array}$ & $\begin{array}{c}25.14 \\
(30.07)\end{array}$ & $\begin{array}{c}6.52 \\
(14.77)\end{array}$ & $\begin{array}{c}15.83 \\
(23.42)\end{array}$ & $\begin{array}{c}35.52 \\
(36.59)\end{array}$ & $\begin{array}{c}16.35 \\
(23.85)\end{array}$ & $\begin{array}{c}25.94 \\
(30.22)\end{array}$ \\
\hline $\mathrm{F}_{2}: 50 \% \mathrm{RDF}$ & $\begin{array}{c}5.24 \\
(13.18)\end{array}$ & $\begin{array}{c}1.88 \\
(7.92)\end{array}$ & $\begin{array}{c}3.56 \\
(10.94)\end{array}$ & $\begin{array}{l}17.79 \\
(24.95)\end{array}$ & $\begin{array}{c}4.77 \\
(12.66)\end{array}$ & $\begin{array}{c}11.28 \\
(19.64)\end{array}$ & $\begin{array}{c}28.27 \\
(22.00)\end{array}$ & $\begin{array}{c}9.99 \\
(18.39)\end{array}$ & $\begin{array}{c}19.13 \\
(25.19)\end{array}$ \\
\hline $\mathrm{F}_{3}: 75 \% \mathrm{RDF}$ & $\begin{array}{c}4.80 \\
(12.66)\end{array}$ & $\begin{array}{c}1.47 \\
(7.03)\end{array}$ & $\begin{array}{c}3.13 \\
(10.14)\end{array}$ & $\begin{array}{l}17.17 \\
(24.50)\end{array}$ & $\begin{array}{c}4.66 \\
(12.52)\end{array}$ & $\begin{array}{c}10.91 \\
(19.18)\end{array}$ & $\begin{array}{l}27.93 \\
31.89)\end{array}$ & $\begin{array}{c}9.05 \\
(17.49)\end{array}$ & $\begin{array}{c}18.49 \\
(24.69)\end{array}$ \\
\hline $\mathrm{F}_{4}: 100 \% \mathrm{RDF}$ & $\begin{array}{c}3.73 \\
(11.09)\end{array}$ & $\begin{array}{c}1.30 \\
(6.50)\end{array}$ & $\begin{array}{c}2.52 \\
(9.10)\end{array}$ & $\begin{array}{c}15.53 \\
(23.18)\end{array}$ & $\begin{array}{c}3.76 \\
(11.24)\end{array}$ & $\begin{array}{c}9.65 \\
(18.05)\end{array}$ & $\begin{array}{c}26.10 \\
(30.64)\end{array}$ & $\begin{array}{c}7.28 \\
(15.63)\end{array}$ & $\begin{array}{c}16.69 \\
(23.14)\end{array}$ \\
\hline $\mathrm{F}_{5}: 125 \% \mathrm{RDF}$ & $\begin{array}{c}4.68 \\
(12.52)\end{array}$ & $\begin{array}{c}0.07 \\
(8.33)\end{array}$ & $\begin{array}{c}3.37 \\
(10.63)\end{array}$ & $\begin{array}{c}16.83 \\
(24.20)\end{array}$ & $\begin{array}{c}4.65 \\
(12.38)\end{array}$ & $\begin{array}{c}10.74 \\
(19.09)\end{array}$ & $\begin{array}{c}27.72 \\
(31.71)\end{array}$ & $\begin{array}{c}8.47 \\
(16.92)\end{array}$ & $\begin{array}{c}18.09 \\
(24.31)\end{array}$ \\
\hline $\mathrm{F}_{6}: 150 \% \mathrm{RDF}$ & $\begin{array}{c}3.70 \\
(11.09)\end{array}$ & $\begin{array}{c}1.42 \\
(6.80)\end{array}$ & $\begin{array}{c}2.56 \\
(9.28)\end{array}$ & $\begin{array}{l}16.13 \\
(23.66)\end{array}$ & $\begin{array}{c}4.42 \\
(12.11)\end{array}$ & $\begin{array}{c}10.27 \\
(18.72)\end{array}$ & $\begin{array}{c}27.13 \\
(31.35)\end{array}$ & $\begin{array}{c}8.01 \\
(16.43)\end{array}$ & $\begin{array}{c}17.57 \\
(23.89)\end{array}$ \\
\hline $\mathrm{F}_{7}: \mathrm{RDF}+2 \%$ DAP spray & $\begin{array}{c}3.87 \\
(11.39)\end{array}$ & $\begin{array}{c}1.36 \\
(6.80)\end{array}$ & $\begin{array}{c}2.61 \\
(9.28)\end{array}$ & $\begin{array}{c}13.00 \\
(21.13)\end{array}$ & $\begin{array}{c}3.77 \\
(11.24)\end{array}$ & $\begin{array}{c}8.38 \\
(16.85)\end{array}$ & $\begin{array}{c}22.30 \\
(27.98)\end{array}$ & $\begin{array}{c}7.13 \\
(15.44)\end{array}$ & $\begin{array}{c}14.72 \\
(21.71)\end{array}$ \\
\hline $\mathrm{F}_{8}: \mathrm{RDF}+1 \% \mathrm{MgSO}_{4}$ spray & $\begin{array}{c}3.80 \\
(11.24)\end{array}$ & $\begin{array}{c}1.30 \\
(6.55)\end{array}$ & $\begin{array}{c}2.55 \\
(9.10)\end{array}$ & $\begin{array}{c}13.50 \\
(21.56)\end{array}$ & $\begin{array}{c}3.67 \\
(11.09)\end{array}$ & $\begin{array}{c}8.58 \\
(17.05)\end{array}$ & $\begin{array}{c}21.10 \\
(27.31)\end{array}$ & $\begin{array}{c}6.90 \\
(15.21)\end{array}$ & $\begin{array}{c}14.00 \\
(21.26)\end{array}$ \\
\hline $\mathrm{F}_{9}: \mathrm{RDF}+1 \% \mathrm{KNO}_{3}$ spray & $\begin{array}{c}3.90 \\
(11.39)\end{array}$ & $\begin{array}{c}1.26 \\
(1.55)\end{array}$ & $\begin{array}{c}2.58 \\
(9.28)\end{array}$ & $\begin{array}{c}14.00 \\
(21.97)\end{array}$ & $\begin{array}{c}3.83 \\
(11.24)\end{array}$ & $\begin{array}{c}8.92 \\
(17.36)\end{array}$ & $\begin{array}{c}20.20 \\
(26.51)\end{array}$ & $\begin{array}{c}6.37 \\
(14.61)\end{array}$ & $\begin{array}{c}13.29 \\
(20.56)\end{array}$ \\
\hline \multirow[t]{2}{*}{ Mean } & $\begin{array}{c}4.52 \\
(12.25)\end{array}$ & $\begin{array}{c}1.83 \\
(7.71)\end{array}$ & $\begin{array}{c}3.18 \\
(10.30)\end{array}$ & $\begin{array}{c}15.57 \\
(23.26)\end{array}$ & $\begin{array}{c}4.45 \\
(12.11)\end{array}$ & $\begin{array}{c}10.51 \\
(18.91)\end{array}$ & $\begin{array}{c}26.25 \\
(30.66)\end{array}$ & $\begin{array}{c}8.84 \\
(17.11)\end{array}$ & $\begin{array}{c}17.55 \\
(23.89)\end{array}$ \\
\hline & $\mathrm{H}$ & $\mathrm{F}$ & HX F & $\mathrm{H}$ & $\mathrm{F}$ & HX F & $\mathrm{H}$ & $\mathrm{F}$ & HX F \\
\hline $\operatorname{SEm} \pm$ & $\begin{array}{c}0.09 \\
(0.14)\end{array}$ & $\begin{array}{c}0.19 \\
(0.29)\end{array}$ & $\begin{array}{c}0.27 \\
(0.41)\end{array}$ & $\begin{array}{c}0.37 \\
(0.29)\end{array}$ & $\begin{array}{c}0.78 \\
(0.62)\end{array}$ & $\begin{array}{c}1.10 \\
(0.88)\end{array}$ & $\begin{array}{c}0.69 \\
(0.47)\end{array}$ & $\begin{array}{c}1.47 \\
(1.00)\end{array}$ & $\begin{array}{c}2.07 \\
(1.41)\end{array}$ \\
\hline $\mathrm{CD}(p=0.05)$ & $\begin{array}{c}0.26 \\
(0.39)\end{array}$ & $\begin{array}{c}0.55 \\
(0.84)\end{array}$ & $\begin{array}{c}\text { N.S } \\
\text { (N.S) }\end{array}$ & $\begin{array}{c}1.06 \\
(0.84)\end{array}$ & $\begin{array}{c}2.24 \\
(1.79)\end{array}$ & $\begin{array}{c}3.17 \\
\text { (N.S) }\end{array}$ & $\begin{array}{c}1.99 \\
(1.35)\end{array}$ & $\begin{array}{c}4.22 \\
(2.87)\end{array}$ & $\begin{array}{c}\text { N.S } \\
\text { (N.S) }\end{array}$ \\
\hline
\end{tabular}

H: Hybrid; F: Fertilizer; RDF: Recommended dose of fertilizer; Figures in parenthesis indicates arcsine values 
Table 9: Effect of levels of N,P.K and foliar sprays of nutrients on seed cotton yield $\left(\mathrm{kg} \mathrm{ha}^{-1}\right)$ of $\mathrm{Bt}$ and non-Bt cotton

\begin{tabular}{lccc}
\hline Treatments & $\mathrm{H}_{1}: \mathrm{Bt}$ & $\mathrm{H}_{2}:$ Non-Bt & Mean \\
\hline $\mathrm{F}_{1}:$ Control & 1589 & 1440 & 1514 \\
$\mathrm{~F}_{2}: 50 \% \mathrm{RDF}$ & 2782 & 2525 & 2654 \\
$\mathrm{~F}_{3}: 75 \% \mathrm{RDF}$ & 2911 & 2716 & 2816 \\
$\mathrm{~F}_{4}: 100 \% \mathrm{RDF}$ & 3086 & 2839 & 2962 \\
$\mathrm{~F}_{5}: 125 \% \mathrm{RDF}$ & 2993 & 2772 & 2883 \\
$\mathrm{~F}_{6}: 150 \% \mathrm{RDF}$ & 3045 & 2782 & 2914 \\
$\mathrm{~F}_{7}: \mathrm{RDF}+2 \% \mathrm{DAP}$ spray & 3168 & 2916 & 3042 \\
$\mathrm{~F}_{8}: \mathrm{RDF}+1 \% \mathrm{MgSO}_{4}$ spray & 3353 & 3127 & 3240 \\
$\mathrm{~F}_{9}: \mathrm{RDF}+1 \% \mathrm{KNO}_{3}$ spray & 3235 & 2998 & 3117 \\
$\mathrm{Mean}$ & 2907 & 2680 & 2783 \\
& $\mathrm{H}$ & $\mathrm{F}$ & $\mathrm{H} \mathrm{X} \mathrm{F}$ \\
$\mathrm{SEm} \pm$ & 56 & 123 & 169 \\
$\mathrm{CD}(p=0.05)$ & 168 & 369 & $\mathrm{NS}$ \\
\hline
\end{tabular}

H:Hybrid F: Fertilizer RDF: Recommended dose of fertilizer nutritional treatments (Shivamurthy and Biradar, 2014). The application of recommended dose of fertilizer based on soil test value along with one spray of each of $1 \%$ and $2 \%$ urea and $1 \% \mathrm{MgSO}_{4}$ during flowering to boll development stage significantly reduced incidence of leaf reddening in Bt cotton and also increased cotton yield and monetary return (Patel et al.2011).The interaction between Bt/non-Bt with different fertilizer doses was found non-significant.

\subsection{Correlation studies}

Leaf concentration of $\mathrm{N}, \mathrm{K}, \mathrm{Fe}, \mathrm{Mg}$ and chlorophyll has significant negative correlation with the intensity of reddening (Table 10). Among these, potassium was the most significant superior factor for reddening $\left(-0.785^{* *}\right)$ followed by magnesium $\left(-0.731^{* *}\right)$, iron $\left(-0.705^{* *}\right)$, nitrogen $\left(-0.699^{* *}\right)$ and chlorophyll $\left(-0.674^{* *}\right)$. The leaf nitrogen content had positive correlation with $\mathrm{Mg}\left(+0.924^{* *}\right), \mathrm{K}\left(+0.807^{* *}\right)$, chlorophyll $\left(+0.758^{* *}\right)$ and $\mathrm{Fe}\left(+0.654^{* *}\right)$. The leaf nitrogen content

Table 10: Correlation coefficient between per cent as plant affected with reddening and mineral nutrient content in the leaves

\begin{tabular}{|c|c|c|c|c|c|c|c|}
\hline & Leaf reddening $(\%)$ & $\mathrm{N}(\%)$ & $\mathrm{P}(\%)$ & $\mathrm{K}(\%)$ & $\mathrm{Fe}(\%)$ & $\operatorname{Mg}(\%)$ & Chlorophyll (mg g-1) \\
\hline Leaf reddening (\%) & 1 & & & & & & \\
\hline N (\%) & $-0.699^{* *}$ & 1 & & & & & \\
\hline P (\%) & 0.044 & 0.085 & 1 & & & & \\
\hline K $(\%)$ & $-0.785^{* *}$ & $0.807^{* *}$ & 0.084 & 1 & & & \\
\hline $\mathrm{Fe}(\%)$ & $-0.705^{* *}$ & $0.654^{* *}$ & -0.027 & $0.808^{* *}$ & 1 & & \\
\hline $\operatorname{Mg}(\%)$ & $-0.731^{* *}$ & $0.924^{* *}$ & 0.050 & $0.825^{* *}$ & $0.667^{* *}$ & 1 & \\
\hline Chlorophyll (mg g $\left.{ }^{-1}\right)$ & $-0.674^{* *}$ & $0.755^{* *}$ & -0.020 & $0.800^{* *}$ & $0.902^{* *}$ & $0.748^{* *}$ & 1 \\
\hline
\end{tabular}

showed significant negative correlation with reddening of leaves $\left(-0.699^{* *}\right)$. This indicated that the increased in leaf nitrogen reduced the reddening in cotton leaves. This might be associated with enhanced vegetative growth of plant, which can accelerate the nutrient uptake by cotton and maintained the proper ratios of nutrients in cotton plant system. The ratio of nitrogen to potassium in cotton leaves also governs the reddening phenomenon. Similarly, the $\mathrm{Fe}$ and $\mathrm{Mg}$ showed the significantly negative correlation with reddening of leaves $\left(-0.705^{* *}\right.$ and $\left.-0.731^{* *}\right)$. The leaf potassium content was significantly and positively correlated with $\mathrm{Fe}\left(+0.808^{* *}\right)$ and $\mathrm{Mg}\left(+0.825^{* *}\right)$. The leaf $\mathrm{Fe}$ content was also positively correlated with $\mathrm{Mg}\left(+0.667^{* *}\right)$. Potassium deficiency is predominant factor for reddening. Probably potash is a cofactor of enzymes involved in biosynthesis of chlorophyll alongwith $\mathrm{Fe}$ and $\mathrm{Mg}$ the deficiency of all these nutrients may result into low biosynthesis of chlorophyll and high synthesis of anthocyanin which impart red colour to cotton leaves. The increased synthesis of chlorophyll might be suppressed the synthesis of anthocyanin pigment $\left(-0.674^{* *}\right)$ in cotton. Anthocyanin imparts the reddening to cotton leaves.

\section{Conclusion}

Application of recommended dose of fertilizer i.e. 100:50:50 $\mathrm{kg} \mathrm{N}: \mathrm{P}_{2} \mathrm{O}_{5}: \mathrm{K}_{2} \mathrm{O} \mathrm{ha}^{-1}$ and the three foliar sprays of mineral nutrients $\left(\mathrm{N}, \mathrm{P}, \mathrm{K}\right.$ and $\mathrm{Mg}$ ) through $1 \% \mathrm{MgSO}_{4}, \mathrm{KNO}_{3}$ and $2 \%$ DAP had reduced the risk of leaf reddening as well as helped in increasing seed cotton yield in Bt and non-Bt cotton hybrids. As per correlation studies potassium deficiency was the most predominant factor for reddening followed by $\mathrm{Mg}$, $\mathrm{Fe}, \mathrm{N}$ and chlorophyll.

\section{References}

Bell, A.A., Nicholas, R.L., Alberts, D., Baird, R., Brown, S., 2006. Bronze wilt of cotton. Available at http://texaserc. tamil.edu.

Brar, M.S., Gill, M.S., Sekhon, K.S., Sidhu, B.S., Sharma, P., Singh, A., 2008. Effect of soil and foliar application of nutrients on yield and nutrient concentration in Bt cotton. Journal of Research 45(3\&4), 126-131.

Chapagain, B.P., Wiesma, Z., 2004. Effect of nutri-vant-peak foliar spray plant development, yield, and fruit quality 
in greenhouse tomatoes. Horticulturae Sienticae102(2), 177-188

Chapman, H.D., Pratt, P.F., 1961. Methods of analysis for soil, plant and water. Division of Agril. Science California University, USA.

CICR., 2014. CICR annual report 2013-14 Available from http://www.cicr.org.in/cicr ar 1314/15 others.pdf.

Hebbar, K.B., Perumal, N.K., Khadi, B.M., 2007. Photosynthesis and plant growth response of transgenic Bt cotton (Gossypium hirsutum L.) hybrids under field condition. Photosynthetica 45, 254-258.

Hussein, M.M., Abd El-Halim, S.M., Talaab, A., 2006. Influence of drought and foliar application on nutrients status in shoots of barley plants. Egypt Journal of Agronomy 28(1), 35-48.

Jackson, M.L., 1973. Soil Chemical Analysis. New Delhi: Prentice Hall of India Pvt. Ltd.

Jadhao, J.G., Jadhao, S.D., Ghodpage, R.M., Ingole, A.S., 2004. Effect of different chemical sprays on reddening and morphological characters in cotton. Punjabrao Deshmukh Krishi Vidyapeeth Research Journal 28, 225-228.

Panse, V.G., Sukhatme, P.V., 1985. Statistical methods for agricultural workers. Indian Council of Agricultural Research, New Delhi Publications.

Patel, K.M., Chaudhari, P., Kumar,V., 2011. Management of leaf reddening in Bt cotton. World Cotton Research Conference-5, Renaissance Convention Centre, Mumbai.

Pettigrew, W.T., 2008. Potassium influences on yield and quality production for maize, wheat, soybean and cotton. Plant Physiology 33(4), 670-681.

Prasad, M., Lal, K., Prasad, R., 2005. Effect of nitrogen and organic plant food supplements and stimulant Vegimax and Mhagrozyme on growth, yield attributes and yield cotton (Gossypium hirsutum). Indian Journal of Agronomy 50, 228-230.

Sadasivam,S., Manickam, A., 1992. In : Biochemical method for Agricultural Science, Wiley Eastern Ltd., New Delhi.

Sekhon, N.K., Singh, C.B., 2013. Plant nutrient status during boll development and seed cotton yield as affected by foliar application of different sources of potassium. American Journal of Plant Sciences 4, 1409-1417.

Shivamurthy,D., Biradar, D.P., 2014. Effect of foliar nutrition on growth, yield attributes and seed cotton yield of $\mathrm{Bt}$ cotton. Karnataka Journal of Agricultural Sciences 27(1), 5-8.

Zoroski, R.J., Bureau, R.G., 1977. A rapid nitric perchloric acid digestion method for multielement tissue analysis. Communications in Soil Science and plant Analysis 8, 425-436. 